\title{
Controlling Bacillus cereus adherence to stainless steel with different cleaning and sanitizing procedures used in dairy plants
}

\author{
[Controle do processo de adesão de Bacillus cereus ao aço inoxidável após diferentes procedimentos \\ de limpeza e sanitização usados na indústria de laticínios] \\ V.C. Salustiano ${ }^{1}$, N.J. Andrade ${ }^{1 *}$, J.I. Ribeiro Junior ${ }^{2}$, P.E. Fernandes ${ }^{1}$, J.P. Lopes $^{1}$, \\ P.C. Bernardes ${ }^{1}$, J.G. Portugal ${ }^{1}$ \\ ${ }^{1}$ Departamento de Tecnologia de Alimentos - UFV \\ Av. P.H. Rolfs, s/n \\ 36570-000 - Viçosa, MG \\ ${ }^{2}$ Departamento de Estatística - UFV - Viçosa, MG
}

\begin{abstract}
Bacillus cereus adherence to stainless steel used to milk contact surfaces was observed, depending on the cleaning and sanitizing procedures applied and the physicochemical properties of the surfaces. Numbers of surviving B. cereus after hygiene procedures were affected by temperature, the concentrations of both alkaline and acid washes, and the $\mathrm{pH}$ of the chlorine solution. The adhesion of $\mathrm{B}$. cereus to the stainless steel was not thermodynamically favorable, and the adherence of this microorganism occurred in lower number, in accordance to the thermodynamic aspect of adhesion.
\end{abstract}

Keywords: Bacillus cereus, equipment surface, dairy industry, hygiene procedures

\section{RESUMO}

Foi observada a adesão de Bacillus cereus em superfície de aço inoxidável em contato com o leite, segundo o procedimento de limpeza, a sanitização e as propriedades físico-químicas da superfície. O número de $B$. cereus viáveis, após os procedimentos de higienização, foi afetado pela temperatura, pela concentração das soluções alcalinas e ácidas e pelo pH da solução clorada. A adesão de $B$. cereus em aço inoxidável não foi termodinamicamente favorável, e ocorreu pouca adesão desse microrganismo, de acordo com os aspectos termodinâmicos da adesão.

Palavras-chave: Bacillus cereus, equipamento, indústria do leite, higienização

\section{INTRODUCTION}

Adhesion processes and biofilm formation can occur on milk contact surfaces postpasteurization (Chmielewski and Frank, 2003; Ryu and Beuchat, 2005). The biological activity of Bacillus cereus leads to undesirable alterations of milk proteins and lipids by proteases and lipases, decreasing the shelf life of the product (Fromm and Boor, 2004). Consumption of food containing more than $10^{5}$ viable $B$. cereus cells/g has been implicated in outbreaks of emetic and diarrheic toxicity. In the bacterial adherence to surfaces, physicochemical properties such as hydrophobicity, electrical charge, and roughness of the surfaces should be taken in account.

Correctly applied cleaning and sanitizing procedures can prevent and control the bacterial adhesion process on equipment surfaces (Griffith, 2005; Lelieveld et al., 2005). Hygiene procedures should be detailed enough to obtain effective removal of organic and inorganic residues, as well as microorganisms from the milk contact surfaces by using cleaners and sanitizer agents correctly. The establishment of

Recebido em 14 de junho de 2009

Aceito em 15 de outubro de 2010

*Autor para correspondência (corresponding author)

E-mail: nandrade@ufv.br 
Sanitation Standard Operating Procedures (SSOP) is very important in controlling the presence of $B$. cereus on milk contact surfaces (Lelieveld et al., 2005; Andrade et al., 2008). The alkaline agents are responsible for fatty acids saponification and for making proteins residues soluble in water by changing of electrical charges of amino acid in high $\mathrm{pH}$. At $\mathrm{pH} 12$ and $60^{\circ} \mathrm{C}$ of cleaning solution the protein residues reach $100 \%$ of solubility. Complexant agents, for example, sodium ethylene diamine tetraacetic acid(EDTA-Na) are able to sequestrate mineral residues such as calcium present in the hard water and in the milk, preventing milk deposit formation on the stainless steel surfaces. Acid solutions, such as prepared with acid nitric, prevent mineral incrustation on the surfaces. Tense active agents such as sodium dodecyl benzene sulphonate decrease the interfacial tension of water improving the contact between residues and cleaners.

The aim of this work was to evaluate the adhesion of $B$. cereus on stainless steel surfaces AISI 304, \#4, by different Sanitation Standard Operations Procedures (SSOP). Also, some physicochemical properties of the stainless steel and $B$. cereus surfaces were studied.

\section{MATERIAL AND METHODS}

The study of $B$. cereus adherence and its control with hygiene procedures was conducted according to the methodology proposed by Gilmour et al. (1993). One milliliter of B. cereus (RIBO 1 222-173-S4) suspension, activated three times in BHI containing approximately $1.0 \times 10^{8} \mathrm{cfu} / \mathrm{mL}$ of bacteria at $32^{\circ} \mathrm{C}$ for $24 \mathrm{~h}$, was added in $100 \mathrm{~mL}$ of whole pasteurized milk. This ribogroup was previously found on four surfaces and also in the milk, indicating the role of the equipment surfaces as reservoirs of $B$. cereus (Salustiano et al., 2009)

The inoculated milk was used to fill four sections of stainless steel pipe (AISI 304, \# 4) with an internal diameter of $3.1 \mathrm{~cm}$ and a length of $33 \mathrm{~cm}$, which was sealed with rubber caps and sterilized at $121^{\circ} \mathrm{C}$ for $15 \mathrm{~min}$. The pipe sections were previously conditioned with raw milk before use with the following procedure: the tubes were conditioned by scrubbing with sodium carbonate $(0.75 \mathrm{~g} / 100 \mathrm{~mL})$ and sodium sulfite
$(0.05 \mathrm{~g} / 100 \mathrm{~mL})$ at ambient temperature (20$25^{\circ} \mathrm{C}$ ), rinsed with cold water, and autoclaved at $121^{\circ} \mathrm{C}$ for $15 \mathrm{~min}$. To complete the conditioning process, the tubes were filled with raw milk, incubated at $22^{\circ} \mathrm{C}$ for $6 \mathrm{~h}$, washed, and sterilized. This procedure was repeated three times.

The pipe sections were placed on a flat surface and, from a central point, rolled three times longitudinally up and down. The pipes were also rolled three times laterally from left to right, and then manually stacked three times in an upright manner. This entire procedure was performed six times across a square template $(46 \mathrm{~cm}$ long) delimited on the bench surface of the laboratory. In sequence, the pipes sections were incubated at $4^{\circ} \mathrm{C}$ for $6 \mathrm{~h}$ to examine bacterial adherence to the stainless steel. This temperature and time simulated the milk storage after pasteurization and the filling of the packages. After the adherence step, the pipe sections were submitted to different cleaning and sanitizing procedures (Table 1). The chosen hygiene procedures represent real situations found in the routine of the dairy plants.

The adhesion process of $B$. cereus and SSOP procedures (Andrade et al., 2008) were performed for five consecutive days over a period of five weeks, with five repetitions per week. After the fifth day, the number of cells remaining on the surfaces of the pipes after the SSOP was determined as follows: initially, sessile cells were removed by filling in the pipe sections with $100 \mathrm{~mL}$ of a quarter-strength Ringer solution - sodium chloride $(2.25 \mathrm{~g} / \mathrm{L})$, potassium chloride $(0.105 \mathrm{~g} / \mathrm{L})$, anhydrous calcium chloride $(0.12 \mathrm{~g} / \mathrm{L})$, sodium bicarbonate $(0.05 \mathrm{~g} / \mathrm{L})$, and sodium thiosulfate $(0.25 \mathrm{~g} / \mathrm{L})$; then the pipes were manually stacked six times and the Ringer solution was discharged. In sequence, pipe sections were filled with $100 \mathrm{~mL}$ Ringer solution and the attached cells were removed from the walls of the tubes using a squeegee sampler, that consisted of a metal rod to which a $3.25 \mathrm{~cm}$ diameter, and 3mm thick neoprene rubber disc was attached, with a $3 \mathrm{~mm}$ diameter drilled hole in each quadrant to allow the passage of rinse solution. The squeegee samplers were individually sterilized and ready for use. The top closures were removed from the pipes and the rod samplers were pushed to the bottom of the pipes. The rods were then drawn up the pipe section until the washer reached $2 \mathrm{~cm}$ from the 
top. This procedure was repeated six times and then the rods were removed. The top of the pipe was closed again and the Ringer solution remained in contact with the surface for a minute. Finally, the pipe sections were stacked again. Aliquots from the Ringer solution were inoculated in the Plate Count Agar (Merck - São Paulo, Brazil) at $32^{\circ} \mathrm{C}$ for $24 \mathrm{~h}$, according to the methodology of Evancho et al. (2001). The results were expressed as $\mathrm{cfu} / \mathrm{cm}^{2}$.

Table 1. Sanitation Standard Operating Procedures for the pipe sections with Bacillus cereus RIBO 1 222-173-S4

\begin{tabular}{ll}
\hline Procedure & Sanitation Standard Operating Procedures \\
\hline & i) Disposal of the inoculums; ii) a pre-washing with distilled water at $25^{\circ} \mathrm{C}$; iii) an alkaline \\
& washing with sodium hydroxide $(10 \mathrm{~g} / \mathrm{L})$, EDTA $(0.4 \mathrm{~g} / \mathrm{L})$, and sodium dodecyl sulphonate \\
& $(0.1 \mathrm{~g} / \mathrm{L}), \mathrm{pH} 13$, at $60^{\circ} \mathrm{C}$; iv) a rinsing with distilled water at $40^{\circ} \mathrm{C}$; an acid washing with \\
Control & $\mathrm{HNO}_{3}(10 \mathrm{~mL} / \mathrm{L}), \mathrm{pH} 1.5$, at $25^{\circ} \mathrm{C}$; rinsing with distilled water at $25^{\circ} \mathrm{C}$, and finally, sanitization \\
& with $100 \mathrm{mg} / \mathrm{L}$ of free available chlorine $(\mathrm{FAC})$, prepared from sodium dichloroisocyanurate, \\
& with a $\mathrm{pH} 7.0-7.5,25^{\circ} \mathrm{C}$. Note: After treating the test tubes with the alkaline, acidic, and \\
& sanitizing solutions, the tubes were submitted to the adherence procedures, as previously \\
& mentioned.
\end{tabular}

Surface hydrophobicity was determined based on contact angle measurements of the stainless steel and $B$. cereus surfaces with water, formamide, and $\alpha$-bromonaphtalene and the surfaces using a goniometer (Kruss ${ }^{\circledR}$, Germany). From the hydrophobicity, the interfacial tension $(\gamma)$, the total free energy of interaction $\left(\Delta \mathrm{G}_{\mathrm{sws}}{ }^{\mathrm{TOT}}\right)$, and global free energy of adhesion between stainless steel and $B$. cereus $\left(\Delta \mathrm{G}_{\text {adhesion }}\right)$ were determined by appropriate formulas (van Oss, 1994).

The total free energy of interaction among molecules of the surface(s) immersed in water (w) was determined by the sum of the apolar and polar free energy of interactiong ${ }_{\text {sws }}{ }^{\mathrm{LW}}$ and $\Delta \mathrm{G}_{\mathrm{sws}}{ }^{\mathrm{AB}}$, respectively.

$$
\begin{aligned}
& \Delta G_{s w s}^{T O T}=\Delta G_{s w s}^{L W}+\Delta G_{s w s}^{A B}(\text { Equation 1) } \\
& \Delta G_{s w s}^{L W}=-2 x \sqrt{\gamma_{s}^{L W}-\gamma_{w}^{L W}}(\text { Equation 2) } \\
& \Delta G_{s w s}^{A B}=-4\left(\sqrt{\gamma_{s}^{+} \gamma_{s}^{-}}+\sqrt{\gamma_{w}^{+} \gamma_{w}^{-}}-\sqrt{\gamma_{s}^{+} \gamma_{w}^{-}}-\sqrt{\gamma_{w}^{+} \gamma_{s}^{-}}\right) \text {(Equation 3) }
\end{aligned}
$$

When $\Delta \mathrm{G}_{\text {sws }}{ }^{\text {TOT }}>0$, the surface is considered hydrophilic, conversely, $\Delta \mathrm{G}$ sws $<0$ the surface is hydrophobic.

$$
\begin{aligned}
& \gamma_{b s}=\gamma_{b s}^{L W}+\gamma_{b s}^{A B} \\
& \gamma_{b s}^{L W}=\gamma_{b}^{L W}+\gamma_{s}^{L W}-2 \sqrt{\gamma_{b}^{L W} \gamma_{s}^{L W}} \\
& \gamma_{b s}^{A B}=2\left(\sqrt{\gamma_{b}^{+} \gamma_{b}^{-}}+\sqrt{\gamma_{s}^{+}} \gamma_{s}^{-}-\sqrt{\gamma_{b}^{+} \gamma_{s}^{-}}-\sqrt{\gamma_{b}^{-}} \gamma_{s}^{+}\right)
\end{aligned}
$$

From the values of the components of the interfacial tensions, it is possible to determine the $\Delta \mathrm{G}_{\text {adhesion }}$ between two surfaces (microbial cells (b) and food processing surfaces (s)): 
As the free energy is related to the interfacial tension, then $\Delta \mathrm{G}_{\text {adhesion }}$ can be represented by the following:

$$
\begin{aligned}
& \Delta G_{\text {adhesion }}=\Delta G_{b l s}^{L W}+\Delta G_{b l s}^{A B} \\
& \Delta G_{b l s}^{L W}=\gamma_{b s}^{L W}-\gamma_{b l}^{L W}-\gamma_{s l}^{L W} \\
& \Delta G_{b l s}^{A B}=\gamma_{b s}^{A B}-\gamma_{b l}^{A B}-\gamma_{s l}^{A B}
\end{aligned}
$$

in which $\gamma_{\mathrm{bs}}$ is the interfacial tension between the bacterial surfaces and the adhesion surface; $\gamma_{\mathrm{b}}$ is the interfacial tension between the bacterial surfaces and the liquid; and $\gamma_{\mathrm{sl}}$ is the interfacial tension between the adhesion surfaces and the liquid.

The $\Delta \mathrm{G}_{\text {adhesion }}$ values allow for evaluation of the thermodynamics of the adhesion process: if $\Delta \mathrm{G}_{\text {adhesion }}<0$, the process is favorable; if $\Delta \mathrm{G}_{\text {adhesion }}>0$, the process is unfavorable.

The roughness was evaluated using Atomic Force Microscopy (AFM) (Universal SPM System Ntegra Prima/NT-MDT) and a perfilometer (Ambios Technology, XP1) in the Nanoscopy Laboratory at the Departamento de Física at the Universidade Federal de Viçosa, Minas Gerais, Brazil.

The electrical charge of the ribotype was determined based in the \% of cells retention in the ionic charge resins (anionic and cationic) by using of electrostatic interaction chromatography. The analyses of electric charge were conducted with the use of SP Sepharose XL and Q Sepharose XL columns (GE Healthcare ${ }^{\circledR}$ ).

The numbers of $\mathrm{cfu} / \mathrm{cm}^{2}$ after different cleaning and sanitizing procedures on $B$. cereus RIBO 1 222-173-S4 adherence to pipe surfaces (stainless steel AISI 304, \#4) were compared with APHA recommendation which is $2 \mathrm{cfu} / \mathrm{cm}^{2}$ ( Evancho et al., 2001) The results concerning physicochemical properties of the surfaces were discussed by descriptive analysis.

\section{RESULTS AND DISCUSSION}

The conditions of the stainless steel surfaces adhered with $B$. cereus for five weeks were dependent on the cleaner and sanitizer agents used in the SSOP. Procedure C was less effective, since after three repetitions, the number of $B$. cereus was higher than $2 \mathrm{cfu} / \mathrm{cm}^{2}$ (Table 2). The recommended value for mesophilic aerobic microorganisms by Evancho et al. (2001) was adopted in this research as a limit for $B$. cereus counts on surfaces to be considered in good hygienic condition for food processing. The probable causes of poor sanitation were the following: a) the low concentration of the alkaline solutions, b) the alkaline solution without the addition of complex agents or caustic active agents, c) the absence of acid washing, and d) the high $\mathrm{pH}$ of the chlorine solution.

Table 2. Number of Bacillus cereus $\left(\mathrm{cfu} / \mathrm{cm}^{2}\right.$ ) adhered to the stainless steel AISI 304, \#4, after different cleaning and sanitizing procedures

\begin{tabular}{lccccc}
\hline \multirow{2}{*}{ Procedure } & \multicolumn{5}{c}{ Repetition } \\
\cline { 2 - 5 } & 1 & 2 & 3 & 4 & 5 \\
\hline Control* $^{*}$ & $<0.85$ & 0.85 & $<0.85$ & $<0.85$ & $<0.85$ \\
A $^{*}$ & $<0.85$ & $<0.85$ & $<0.85$ & $<0.85$ & 0.85 \\
B $^{*}$ & $<0.85$ & 1.70 & 0.85 & $<0.85$ & 0.85 \\
C $^{*}$ & 2.51 & 0.85 & 2.98 & $<0.85$ & 2.13 \\
\hline
\end{tabular}

*Procedures performed according to Table 1 .

Procedure $\mathrm{B}$ showed the number of adhered $B$. cereus to be a little higher than the numbers found in procedure A and the control. However, the microbial counts after procedure $\mathrm{B}$ were lower than the specification $\left(2 \mathrm{cfu} / \mathrm{cm}^{2}\right)$. The bacterial removal by procedure A and the control were much closer. In this experiment, it seemed that the absence of the tense active agent and a chlorine solution concentration lower than generally recommended did not affect the outcome of the procedures. However, it is important to mention the role of the tense and active agents in cleaning formulations, which have the effect of decreasing the surface tension of water and improving the contact between the detergent and food residues (Andrade et al., 2008). 
The effectiveness of the hygiene treatments was reduced when the concentration (Procedure B) and temperature (Procedure $\mathrm{C}$ ) of the alkaline solution was decreased, thus showing the importance of controlling these factors for the prevention of microbial contamination of the surfaces. The removal of food residues from the surfaces by cleaning agents before sanitization is fundamental for microbiological control.

Peng et al. (2001) showed that the fibrils of Bacillus cereus were responsible for the adherence of the microorganism to stainless steel, and they were not removed without previous cleaning with detergents. Peng et al. (2002) observed a higher reduction in the numbers of microorganisms on the surfaces that was due to the actions of the alkaline detergent. The steps of acid washing and sanitization did show a significant reduction in the microbial population of $B$. cereus remaining on the surfaces. However, the importance of the acid detergent and sanitizers should be stressed. The acid solutions are very important in controlling and preventing mineral deposits on the equipment surfaces, which are responsible for the corrosion process and support points where biofilms can start. The sanitizer solutions are responsible for reducing microorganisms to levels considered safe for food processing and limiting food spoilage by eliminating these pathogenic microorganisms. Therefore, the hygiene procedures should be conducted in two basic steps: cleaning by using detergents to remove organic and inorganic food residues, and sanitizing by the use of physical or chemical agents to control microorganisms.

The cleaning and sanitizing procedures are affected by several surface physicochemical properties of the stainless steel and the microorganisms. Among them, surface hydrophobicity, roughness, and electrical charge are included. Some physicochemical analysis of the stainless steel and B. cereus evaluated in this study are showed in Table 3 . The roughness of the surfaces of stainless steel $(\mathrm{Ra}=0,22 \mu \mathrm{m})$ can be considered smooth. Generally, when the mean roughness $(\mathrm{Ra})$ is approximately of the bacterial size (about $1.0 \mu \mathrm{m}$ ), the adherence process is favored. The studied strain of $B$. cereus was considered hydrophilic while the stainless steel was considered hydrophobic. The adhesion was not thermodynamically favorable $\left(\Delta G_{\text {adhesion }}=2.55 \mathrm{~mJ} / \mathrm{m}^{2}\right)$ between the stainless steel and the studied strain of $B$. cereus. Thus, the interaction between them was not favored by thermodynamic aspect of adhesion.

Table 3. Some physicochemical characteristics of stainless steel and B. cereus

\begin{tabular}{lcc}
\multicolumn{1}{c}{ Physicochemical characteristics } & Stainless steel & B. cereus \\
\hline Mean roughness-Perfilometry (Ra) & $0.22 \mu \mathrm{m}$ & - \\
Mean roughness- Atomic Force Microscopy (Ra) & $83.35 \mathrm{~nm}$ & - \\
Electrical anionic resin (\% of retention) & - & 89.82 \\
Electrical cationic resin (\% of retention) & - & 90.96 \\
Contact angle with water $\left(\theta_{\mathrm{A}}\right)$ & 70.77 & 24.52 \\
Interfacial tension $\left(\mathrm{mJ} / \mathrm{m}^{2}\right)$ & 40.83 & 56.52 \\
Total free energy of interaction $\left(\Delta \mathrm{G}_{\text {sws }}{ }^{\mathrm{TOT}}\right)\left(\mathrm{mJ} / \mathrm{m}^{2}\right)$ & -28.73 & 19.81 \\
Global free energy of adhesion $\Delta\left(\mathrm{F}_{\text {adhesion }}\right)$ between stainless & & \\
steel and B.cereus $\left(\mathrm{mJ} / \mathrm{m}^{2}\right)$ & & 2,55 \\
\hline
\end{tabular}

The dairy industry should carefully evaluate its SSPO, focusing on the steps of the pre-rinse with water, the use of the detergents (alkaline and acid), the post-rinse with water, and the use of sanitizers. The SSPO should include adequate information about the concentration, time, and temperature of the cleaning and sanitizing applications.

Finally, the quality of surfaces for food processing should be periodically monitored to detect deviations from the proposed specifications, permitting corrective action to be taken when necessary. Despite of physicochemical properties of the stainless steel AISI 304, \#4, and B. cereus RIBO 1 222-173-S4 were not favored to adhesion process, after the different hygiene procedures, a number ranging $0.85 \mathrm{cfu} / \mathrm{cm}^{2}$ to $2.98 \mathrm{cfu} / \mathrm{cm}^{2}$ was counted on the stainless steel. Then, it can be concluded that the adherence of $B$. cereus occurred in lower number, in accordance to the thermodynamic aspect of adhesion. 


\section{CONCLUSIONS}

The number of $B$. cereus RIBO 1 222-173-S4 found on stainless steel surface AISI 304 \# 4, reached $2.98 \mathrm{cfu} / \mathrm{cm}^{2}$. The number of this microorganism on the surface was dependent on the cleaning and sanitization procedures, being affected by composition of the detergent and temperature applied. The control treatment that used an alkaline detergent at $80{ }^{\circ} \mathrm{C}$ (sodium hydroxide, EDTA, and sodium dodecyl sulphonate), an acid detergent (nitric acid), and a chemical sanitizer (sodium hypochlorite) was the best in the control of the adhesion of $B$. cereus on the surface, reaching $<0.85 \mathrm{cfu} / \mathrm{cm}^{2}$. The adherence of this microorganism occurred in lower number, in accordance to the physical and chemical aspects of adhesion, once the $\Delta \mathrm{G}_{\text {adhesion }}$ was $2.55 \mathrm{~mJ} / \mathrm{m}^{2}$, being not thermodynamically favorable.

Equipment surfaces play an important role in the recontamination of pasteurized milk, especially if hygiene procedures are not correctly applied. To control B. cereus, the dairy industry must emphasize how to conduct the cleaning and sanitizing procedures, with details about the procedure, the control of $\mathrm{pH}$, the concentrations of reagents to be used, and the temperatures and exposure times of the solutions. Also, it is important to establish a monitoring process for assessing corrective actions that can be conducted when necessary.

\section{ACKNOWLEDGEMENTS}

We thank to the Conselho Nacional de Ciência e Tecnologia (CNPq/Brazil) and the Fundação de Amparo à |Pesquisa do Estado de Minas Gerais (FAPEMIG/Brazil) for the financial support.

\section{REFERENCES}

ANDRADE, N.J.; PINTO, C.L.O.; ROSADO, M.S. Controle da higienização na indústria de alimentos In: ANDRADE, N.J. (Ed). Higiene na indústria de alimentos - Avaliação e controle da adesão e formação de biofilmes bacterianos. Viçosa: Varela, 2008. p.181-226.

CHMIELEWSKI, R.A.N.; FRANK, J.F. Biofilm formation and control in food processing facilities. Compr. Rev. Food Sci. Food Saf., v.2, p.22-32, 2003.
EVANCHO, G.M.; SVEUM, W.H.; MOBERG, L.J. et al. Microbiological monitoring of the food processing environment. In: DOWNES, F.P.; ITO, K. (Eds). Compendium methods for the microbiological examination of foods. 4.ed. Washington: APHA, 2001. Chapter 3, p.25-35.

FROMM, H.I.; BOOR, K.J. Characterization of pasteurized fluid milk shelf-life attributes. $J$. Food Sci., v.69, p.207-214, 2004.

GILMOUR, A.; WILSON, A.B.; FRASER, T.W. Microbial adherence to food contact surfaces. In: DENYER, S.P.; GORMAN, S.P.; SUSSMAN, M. (Eds). Microbial Biofilms: formation and control. Oxford: Blackwell Scientific, 1993. p.352.

GRIFFITH, C. Improving surface sampling and detection of contamination. In: LELIEVELD, H.L.M.; MOSTERTE, A.; HOLAH, J. (Eds). Handbook of hygiene control in the food industry. Cambridge: Woodhead, 2005. Chapter 36, p.588-618.

LELIEVELD, H.L.M.; MOSTERTE, A.; HOLAH, J. Handbook of hygiene control in the food industry. Cambridge: Woodhead, 2005. p.744.

PENG, J.L.; TSAI, W.C.; CHOU, C.C. Surface characteristics of Bacillus cereus and its adhesion to stainless steel. Int. J. Food Microbiol., v.65, p.105-111, 2001.

PENG, J.S.; TSAI, W.C.; CHOU, C.C. Inactivation and removal of Bacillus cereus by sanitizer and detergent. Int. J. Food Microbiol., v.77, p.11-18, 2002.

RYU, J.H.; BEUCHAT, L.R. Biofilm formation and sporulation by Bacillus cereus on a stainless steel surface and subsequent resistance of vegetative cells and spores to chlorine, chlorine dioxide, and a peroxyacetic acid-based sanitizer. J. Food Prot., v.68, p.2614-2622, 2005.

SALUSTIANO, V.; ANDRADE, N.; SOARES, $\mathrm{N}$. et al. Contamination of milk with Bacillus cereus by post-pasteurization surface exposure as evaluated by automated ribotyping. Food Control, v.20, p.439-442, 2009.

VAN OSS, C.J. Interfacial forces in aquesous media. New York: Marcel Dekker, 1994. 